beyond dispute that the better a doctor's postgraduate experience the more he has to compromise his medical standards in N.H.S. general practice. Tradition has made many general practitioners and consultants believe that these two areas of medical practice are mutually exclusive, but, as many of us who have experience of North America know, and indeed, as the report clearly showed, this is simply not so. While it may be true that the Canadian general practitioner mentioned in the report admitted many patients to hospital whom his British colleague would care for at home, the report should have underlined that he similarly cares for a number of patients whom his British counterpart would have had to "lose" to the locial hospital.

The number of general-practitioner beds in type 1 (acute) hospitals in England and Wales has remained static at about 7,000 for the past five years-about 300 hospitals offering these facilities. It is lamentable and significant that not one teaching hospital is included in this list. It is depressing to see new hospitals developed and old huspitals modernized without any reference to the needs of the general practitioners in the district. It is up to the Ministry to break down the barriers, and this would represent the cheapest method of retaining young practitioners in this country. It only requires foresight.-I am, etc.,

$$
\begin{aligned}
& \text { Bottisham, } \\
& \text { Cambridge. }
\end{aligned} \text { N. A. Silverston. }
$$

\section{Health Centres}

SIR,-I would like to add my support to Dr. A. M. Rankin's letter (10 February, p. 383) in which he criticizes the drift towards health centres. The growing enthusiasm of some elements of the profession in support of this pulicy appears to be shared by the Minister of Health. This in itself is an immediate cause fur suspicion. The health centre protagonists seem to consider that better facilities and organization which might be available would lead to better general practice.

In my judgement this view is quite erroneous, and it seems obvious to anybody who has given the matter any thought that there is nothing that can be done in a health centre that cannot be done equally as well in privately owned, efficiently run group practice premises. Dr. Rankin's point that, in the event of a dispute with the Government concerning remuneration or other matters, withdrawal of our services would be extremely difficult is well made. All of us who have followed the history of our relationship with the Ministry of Health in the recent disputes must realize that things might have taken a much more serious turn if we had been dependent on the Government for our premises. Furthermore, widespread use of health centres would inevitably lead to a salaried service and the complete subservience of general practitioners to the Ministry of Health and the Government. Although this policy is so beloved by many of our leftwing theoreticians, I do not believe that it commends itself to the majority of us who still desire to remain independent contractors.

I would like to urge our negotiators to be verv wary of committing the profession to Government-owned premises without first ascertaining that this is in fact what the majority desire. In my view, health centres will not improve the treatment of our patients or the services we provide. That will depend on the individual doctor. The millions of pounds necessary to establish these buildings would be better spent in added inducements to modern group practice and general raising of standards in the context of the above remarks.-I am, etc.,

Hornchurch, Essex.

D. D. Cowren.

\section{Electrocardiograph Service for General Practitioners}

SIR,-Dr. J. Seymour and others (3 February, p. 305) have done a service by recording their experience with an electrocardiograph service for general practitioners. Aberdeen Royal Infirmary has been running a similar scheme for 15 years, and our experience is broadly similar to that of the Middlesex Hospital. There is no doubt about the popularity of the service with the general practitioners, nor about its value in the identification of arrhythmias and in the positive diagnosis of a proportion of acute infarcts. But, as Dr. Seymour and his colleagues emphasize, the system has serious limitations which must be fully recognized.

The first of these is that a normal E.C.G. does not exclude coronary arterial diseaseeven with impending infarction; and all our report forms carry a clear statement to this effect. The second limitation is the difficulty, with our present knowledge, of diagnosing infarction in a hypertrophied left ventricle. The third and greatest limitation of such a scheme lies in the frequency with which minor $S T$ and $T$ wave abnormalities are found. As Evans ${ }^{2}$ has repeatedly emphasized, such abnormalities may be vital clues to the diagnosis of coronary heart disease-but they are non-specific. They may be simulated by left ventricular hypertrophy in a patient with a big chest in whom the usual voltage changes are lacking. They may also be simulated by acute benign myocarditis-a condition which may closely mimic a slight coronary attack and is probably much commoner than is at present recognized. If minor changes are ignored, much of the value of the E.C.G. in the early detection of coronary heart disease is lost. If, on the other hand, the report includes the words "possibly ischaemic" much anxiety may be caused to those with benign conditions.

A great deal more knowledge is needed about the minor E.C.G. abnormalities of myocardial infarction before such a service as this can be unreservedly recommended.-I am, etc.,

$$
\begin{aligned}
& \text { Cardiology Department, DAvID SHORT. } \\
& \text { Aberdeen Royal Infirmary, } \\
& \text { Aberdeen. } \\
& \text { REPBRENCB } \\
& \text { ' Evans, W., Brit. Heart F., 1965, 27, } 856 .
\end{aligned}
$$

\section{Geriatric Problems}

SIR,-Dr. F. A. Binks's article on geriatrics in the hospital service (3 February, p. 269) deserves the urgent consideration of all hospital planning authorities. His comments on the correct deployment of hospital services are particularly relevant.

The exploding population of the elderly which precipitated the development of the present organization of geriatric hospital services for the first time caused well-qualified specialist physicians to treat the patient within the community and to make sure by methods of assessment that every hospital bed was utilized for patients really needing such services. At the same time the development of the geriatric day hospital has enabled many patients who would previously have become chronic hospital patients to be treated much more economically. Furthermore, the geriatric day hospital as fully developed at Newsham General Hospital has demonstrated that complicated investigations which used to necessitate admission to hospital can now be done on a day basis on old people. In addition, complicated medical techniques such as blood transfusions can also be performed on patients in the day hospital where appropriate. It is interesting to note that the same advances have not occurred in relation to younger patients, and so one sees on the so-called "acute wards" many patients admitted for investigation or for inpatient treatment which could be provided either at home or on a day basis. Diabetes mellitus particularly is a condition which lends itself to stabilization at outpatients, and yet one still sees such cases admitted to acute medical wards.

It is only in the old age group that social conditions make hospitalization in a considerable percentage of patients a necessity, and if such patients are to be relegated to the geriatrician as soon as the general physician has failed to have a success in their treatment then obviously the whole ratio of acute to geriatric beds must be altered.

There are only two alternative avenues open for future hospital planners in relation to the greatly increased needs of the elderly population. Namely, that there should be a much smaller number of acute beds for the general physicians and a much larger number of geriatric beds, or that all general physicians should have a good grounding in geriatrics and responsibility in developing the same streamlining in geriatric rehabilitation that the pioneers in this science have achieved.

The rocketing costs of the hospital service make it essential that beds should exist for patients and not for doctors and that the right patient should be in the right bed at the right time.-I am, etc., \section{Newsham General Hospital,
Liverpool 6.}

Wilfred Fine.

\section{Subclinical Malabsorption in Thailand}

SIR,-Dr. F. J. Troncale and his associates have recently reported (9 December, p. 578) their finding that intestinal function was unimpaired in a group of 40 residents of Thailand who had jejunal morphologic abnormalities. The data in their article may be subject to interpretation other than that presented by the authors. Mean xylose excretion was found to be within normal limits in the 40 Thais, a finding which, as the authors point out, is similar to that previously described in comparable populations in East Pakistan $^{1}$ and Puerto Rico. ${ }^{3}$ It would seem to this writer, however, that in studies of this nature the only values that are of significance are those for each individual subject and that mean values are both irrelevant and often misleading. Thus 15 of the $39(38 \%)$ sub- 
jects studied by Troncale et al. did in fact have a subnormal value for xylose absorption, as did individual subjects in both of the two references cited by Troncale et al., in which mean values were normal. ${ }^{13}$ Other studies among comparable asymptomatic populations have revealed malabsorption of xylose in $68 \%$ of those previously studied in Thailand by Sprinz et al. ${ }^{3}$ in $40 \%$ in East Pakistan,' in $68 \%$ in West Pakistan, ${ }^{4}$ in $20 \%$ in South India, ${ }^{3}$ in $57 \%$ and in $37 \%^{\circ}$ in two separate studies in Puerto Rico, and in $100 \%$ in rural Haiti. ${ }^{8}$ Thus, far from refuting previously reported findings from Thailand and elsewhere, Troncale et al. have presented corroborative evidence. Impaired absorption of lactose was also found to be universal among the Thais studied by Troncale et al., who dismissed the possibility that this may be additional evidence for an acquired functional defect of the diseased intestinal mucosa. However, such may well be the case in view of the facts that (1) evidence has not been presented which indicates that Thais have a genetic predilection for deficiency of lactase and (2) it is well recognized that lactase deficiency can be acquired both in tropical sprue $^{910}$ and in protein malnutrition. ${ }^{11}$

Troncale et al. conclude that their data militate against the hypothesis that the intestinal lesion found both in overt tropical and in asymptomatic individuals may in some instances be related, since, as they state: " these results [of xylose absorption in asymptomatic Thais] are clearly higher than those found in classical tropical sprue." This writer finds himself increasingly hard put to know exactly how one defines "classical" tropical sprue and is unaware of any set range of reduced values of xylose absorption that are characteristic for overt tropical sprue, but he would like to point out that values similar to those found in some asymptomatic Thais by Troncale et al. have been noted in individual patients with overt tropical sprue who have been seen both at this $\operatorname{clinic}^{8-12}$ and elsewhere. ${ }^{13} \quad$ O'Brien and England have reported that xylose absorption in British soldiers with overt tropical sprue in Malaya became progressively more impaired as the intestinal lesion became more severe in advanced cases. ${ }^{13}$ Thus, one might anticipate that impairment of xylose absorption would in most instances be less severe in asymptomatic subjects than in patients with overt tropical sprue, a fact which we have ascertained to hold for the rural population of Haiti. ${ }^{14}$

Finally, Troncale et al. have neglected to supply one essential piece of information. Does tropical sprue exist in Thailand? This writer is unaware of any publication in the English literature confirming the existence of this disease in that country. Nonspecific jejunal abnormalities have been found among a high proportion of the asymptomatic population in both Africa ${ }^{15}$ and the Middle East, ${ }^{10}$ areas in which overt tropical sprue is not recognized. In these circumstances no one has proposed that the intestinal lesion in these subjects bears any relationship whatsoever to tropical sprue. Unless tropical sprue does indeed exist in Thailand, the observation presented by Troncale $e t$ al., while of interest in that they confirm previous ohservations made by others in Thailand and elsewhere, probably have little relevance to the issue of whether the intestinal lesion found in asvmptomatic subjects in South India, Puerto Rico, and Haiti has a relationship to that found in subjects with overt tropical sprue in these areas.-I am, etc.,

Frederick A. Klipstein.

\section{Columbia University College} of Physicians and Surgeons,

REFERENCES

2 Lindenbaum, J., Alam, A. K. M. J., and Kent, T. H., Brit. med. F., 1966, 2, 1616

Gardner, F. H., and Santiago, B. P. Arch. intern. Mcd., 1956. 98, 467.

prinz, H., Sribhibhadh. R., Gangarosa, E. J. Banyaiati. C.. Kundel, D., and Halstead,
Amer. I. clin. Puth., 1962, 38. +3 . T. Dis.. 1966, 11, 296 .

- Baker, S. J. Ignatius, M. Mathan V I Vaish, S. K., and Chacko, C. C., in Cibs Foundation Siudy Group No. 14 on Intestinal Biopsy, edited by G. E. W. Wolstenholme and M. P. Cameron. ${ }^{1962}$ p. 84 . London.

Robins, S. J., Garcia-Palmieri, $M$. and Rubio, C., Ann. intern. Med., 1967. 66, 556.

Angel, C. R.. Guerra, R., Martinez, J., and
Plough, I. C.. Fed Proc., 1963, 22, 550. Klipstein, F. Ä., Ann. intern. Med., 1967, 66,

Sheehy, T. W., and Anderson, P., Lancet, 1965, Desai, H. G.. Chitre, A. V.. Parekh, D. V., and Jejeebhoy, K. N., Gastroenterology, 1967, 53, Bowie. M. D. Brinkman, G. L.,
J. D. L., F. Pediat. 1965, 66. 1083. 12 Klipstein. F. Pediat. 1965. 66. 1083.964 . 17.457 ${ }_{13}$ O'Bstein. F. A.. Gastroenterology, 1964, 47, 457 f. 1966. 2, 1157.
and Schenk, E. A., Amer. f. clin. Nutr., in

is Banwell, J. G. Hutt, M. S. R., and Tunnicliffe, R. E. Afr. med. J, 1964, 41, 46.

Parkins, R. A., Eidelman, S., Perrin, E. B., and
Rubin, C. E., Amer. Y. clin. Nutr., 1966, 18, 134.

\section{Haemophilus Epiglottitis}

SIR,-Among their 22 fatal cases of respiratory infection in childhood the Newcastle group of doctors (Dr. P. S. Gardner and others, 11 November 1967, p. 316) included one case of haemophilus epiglottitis. This condition, they write, appeared to be particularly serious and may often remain unrecognized. This is especially unfortunate, since it has been contended that in areas of the U.S.A. where doctors are alert to the occurrence of this illness prompt recognition and treatment with tracheotomy and appropriate antibiotics result in a high recovery rate.

We can confirm that the condition may indeed be relatively frequent and rapidly fatal on the strength of the following two cases, which we were able to study in the course of the last two months. The first occurred before the publication of the Newcastle report and the second after it. We did not succeed in growing any pathogens in the first case from post-mortem material collected by the usual methods, but, thanks to the information contained in the report, Haemophilus influenzae was grown from the epiglottis of the second case.

Case 1.-A previously completely healthy boy aged 3 years vomited suddenly one evening and then became dyspnneic. His conditinn worsened and the $f: l l$ wing afternonn he was admitted to hospital with laryngeal stridnr. tachypniea, and tachycardia. He was treated with ampicillin cloxacillin, chlorpromazine, and digoxin, but collapsed a few hnurs after admissinn, and despite full resuscitation measures, including laryngoscopy and intubation, died eight hnurs after admissinn. There was never at any time clinical indication of respiratory obstruction sufficient tn require intuhati $n, n \wedge r$ was this measure helpful when perfarmed. Necrnpsy was performed on cornner's instructions 12 hours after death. The epiglotus was found to stand out sentinelwise, red and swollen. The aryepiglottic folds were likewise inflamed and somewhat nodular. The anterior part of the laryngeal vestibule was roughened and in part covered by a pale membrane. The trachea and main bronchi were grossly inflamed and contained blood-stained serous exudate. The lungs were completely collapsed. The brain was grossly oedematous and the cerebral convolutions flattened. No bacterial path $\%$ gens could be isolated from swabs taken from the nose, epiglottis, larynx, or lungs. This may have been due to the effect of the antibiotics. The results of HeLa, monkey kidney, and human amnion cell inoculation with bronchial and laryngeal exudate for viruses were negative, and so was suckling mouse inoculation. Histological examination of the epiglottis and larynx showed gross mucosal infiltration with pus cells. The lungs showed collapse but no bronchopneumonia.

Case 2.-This 18-month-old boy went off his fond for a day or two before he began vomiting one night at 11 p.m. At 3 a.m. the following morning he developed stridor and became dyspnoeic and cyanotic. On admission to hospital at $10.30 \mathrm{a} . \mathrm{m}$. he was found to have pyrexia and enlarged cervical glands. He was treated with ampicillin, cloxacillin, mist tent, and oxygen. There was intercostal recession, but this improvel somewhat on treatment. However, an hour later he collapsed; immediate intubation was performed without difficulty, but there was no improvement, and he died shortly thereafter within one and a half hours of admission. Necropsy was performed, again on cornner's order, 47 hours after death. As in the previous case there was epiglottitis and laryngitis. The lungs were oedematous and showed scattered intrapulmonary haemorrhage. In this case small quantity of serum broth was iniected into and aspirated from the submucosal tissue of the epiglottis, and Haemophilus influenzae Pittman type b was grown from this specimen.

The brain, as in Case 1, showed marked ocdema. Histological examination of the tissues is not yet complete.

It seems to us that not only clinicians but pathologists should be aware of haemophilus epiglottitis, since the condition may not only be rapidly fatal but is easily overlooked, and the organisms are difficult to grow in such cases. $^{2}$ In spite of stridor and croup in our two cases the fatal outcome was not due to upper respiratory obstruction, and intubation was not helpful. Death was probably caused by pulmonary collapse, peripheral circulatory failure, and rapidly developing cerebral oedema.-We are, etc.,

L. Crome.
MAGDOLNA ERdohAzi.
DAVID LAWSON.
Queen Mary's Hospital
for Children.
Carshalton, Surrey.

REFERENC:B

Turk, D. C., and May. J. R., Hacmophilus influ-

\section{Idiopathic Facial Palsy}

Sir,-Dr. D. Taverner and his colleagues (9 December, p. 581) state that A.C.T.H. gel should be used routinely for the treatment of idiopathic facial palsy, claiming to have shown that it reduces the incidence of denervation from $40 \%$ to $13 \%$. They also claim that cases which suffer denervation despite this treatment have a better resultthat is, denervation is less severe (or reinnervation more successful ?). A so-called "shift to the right."

Such sweeping claims require close examination, since they are not based upon a con- 